\title{
An overview of NMR-based metabolomics to identify secondary plant compounds involved in host plant resistance
}

\author{
Kirsten A. Leiss • Young H. Choi • \\ Robert Verpoorte $\cdot$ Peter G. L. Klinkhamer
}

Received: 26 November 2009/Accepted: 22 January 2010/Published online: 3 April 2010

(C) The Author(s) 2010. This article is published with open access at Springerlink.com

\begin{abstract}
Secondary metabolites provide a potential source for the generation of host plant resistance and development of biopesticides. This is especially important in view of the rapid and vast spread of agricultural and horticultural pests worldwide. Multiple pests control tactics in the framework of an integrated pest management (IPM) programme are necessary. One important strategy of IPM is the use of chemical host plant resistance. Up to now the study of chemical host plant resistance has, for technical reasons, been restricted to the identification of single compounds applying specific chemical analyses adapted to the compound in question. In biological processes however, usually more than one compound is involved. Metabolomics allows the simultaneous detection of a wide range of compounds, providing an immediate image of the metabolome of a plant. One of the most universally used metabolomic approaches comprises nuclear magnetic resonance spectroscopy (NMR). It has been NMR which has been applied as a proof of principle to show that metabolomics can constitute a major advancement in the study of host plant resistance. Here we give an overview on the application of NMR to identify candidate compounds
\end{abstract}

K. A. Leiss $(\square) \cdot$ Y. H. Choi · R. Verpoorte

P. G. L. Klinkhamer

Section Plant Ecology and Metabolomics, Institute

of Biology, Leiden University, Sylviusweg 72,

2333 BE Leiden, The Netherlands

e-mail: K.A.Leiss@Biology.leidenuniv.nl for host plant resistance. We focus on host plant resistance to western flower thrips (Frankliniella occidentalis) which has been used as a model for different plant species.

Keywords Eco-metabolomic approach · Host plant resistance $\cdot$ NMR metabolomics .

Secondary plant metabolites .

Thrips (Frankliniella occidentalis)

\section{Introduction}

Plants produce an immense number of secondary compounds to interact with beneficial or harmful organisms. These compounds mainly act as signal compounds and chemical defence (Wink 2003). Plant defence chemicals repel, restrain or kill plant enemies. An extensive overview of the different groups of secondary metabolites involved in plant defence has been given by Bennett and Wallsgrove (1994). The rich chemical diversity of plants is the result of ongoing evolutionary processes. Mutation and gene duplication lead to a continued formation of new chemical structures that will be selected for if they convey an adaptive advantage to the plant (Grotewold 2005; Benderoth et al. 2006). The more than 200,000 known secondary metabolites provide a potential source for the generation of host plant 
resistance and development of biopesticides (Hartmann 2007).

This is especially important in view of the rapid and vast spread of agricultural and horticultural pests worldwide. Years of selection for yield or palatability traits greatly reduced phenotypic and genetic diversity and may thus have led to loss of resistance (Kennedy and Barbour 1992). At the same time there has been a massive increase in international trade of plants and plant parts, leading to the accidental introduction of many pests. Journeys become faster and climatic differences between countries have little effect when movements are between green houses. In this way major pests on a range of crops, throughout the world, developed resulting in substantial economic losses.

Pest control mainly depends on the use of pesticides. The efficacy of chemical control is limited in part due to pests feeding inside plant organs and in part due to deposition of eggs into sub-epidermal tissues. Furthermore, most chemicals have a shortterm effectiveness and frequent spraying is required. Such excessive use of pesticides has led to resistance of many pests to various insecticides as reviewed in Denholm and Rowland (1992). In addition, it has resulted in a residue problem on marketable crops. This gained special importance in the European Union due to the new regulations for maximum residue limits and safety intervals. At the same time adaptation to new European Union regulation regarding pesticide registration and application resulted in a decreased availability of insecticides (Coelho 2009). Besides the risks for human health, problems arise with toxicity towards non-target beneficial organisms and contamination of the environment.

Multiple tactics in the framework of an integrated pest management (IPM) programme are necessary. This approach represents an array of complementary methods with use of pesticides as the last resort (Dent and Elliott 1995). One important strategy of IPM is the use of chemical host plant resistance. Up to now the study of chemical host plant resistance has, for technical reasons, been restricted to the identification of single compounds applying specific chemical analyses adapted to the compound in question. In biological processes however, usually more than one compound is involved. Looking at different compounds at the same time decreases the ability of pests to brake through host plant resistance. Metabolomics allows the simultaneous detection of a wide range of compounds, providing an immediate image of the metabolome of a plant. One of the most universally used metabolomic approaches comprises nuclear magnetic resonance spectroscopy (NMR). It has been NMR which has been applied as a proof of principle to show that metabolomics can constitute a major advancement in the study of host plant resistance. Here we give an overview on the application of NMR to identify candidate compounds for host plant resistance focusing on host plant resistance to western flower thrips (Frankliniella occidentalis), which has been used as a model for different plant species.

\section{NMR-based metabolomics}

NMR spectroscopy measures the resonances of magnetic nuclei such as ${ }^{1} \mathrm{H},{ }^{13} \mathrm{C}$ and ${ }^{15} \mathrm{~N}$ that interact with an external magnetic field (Hatada and Kitayama 2004). It offers non-invasive structural analysis of metabolites in crude extracts, cell suspensions, intact tissues or whole organisms allowing in vivo analysis (Fan and Lane 2008). NMR spectra are unique and specific for each single compound (Verpoorte et al. 2007, 2008) and can be used to identify metabolites of biological origin of which no a-priori knowledge is needed (Fan and Lane 2008). The latter makes the need for authentic standards, often a major barrier to structure determination, unnecessary. Definitive structural information with no restrictions relating to volatility, polarity or the presence of specific chromophores is given (Fan 1996; Verpoorte et al. 2008). The NMR method provides simultaneous access to both qualitative and quantitative information since the signal intensity is directly proportional to the molar concentration (Pauli et al. 2005). NMR requires minimal sample preparation, is highly reproducible (Fan 1996; Verpoorte et al. 2008) and allows a high sample throughput (Fan and Lane 2008). The quality of an NMR analysis is not dependent on the number of signals detected but on the number of metabolites identified. To facilitate the identification of metabolites databases of NMR spectra of common plant metabolites are needed. The development of such an extensive databases has contributed to the development of NMR, into a fast, convenient and effective metabolomic tool (Verpoorte et al. 2007, 2008), despite the low intrinsic sensitivity (Kopka et al. 2004; Krishnan et al. 2005). To enhance sensitivity, 
selectivity and spectral resolution two-dimensional NMR is applied. Correlated spectroscopy (COSY), heteronuclear multiple quantum coherence (HMQC) spectroscopy, heteronuclear single quantum coherence (HSQC) spectroscopy and heteronuclear multiple bond coherence (HMBC) spectroscopy improve metabolite identification by providing information on the relationship between the signals from two different nuclei (Ratcliffe and Shachar-Hill 2005; Ratcliffe et al. 2001).

\section{General application of NMR in plant metabolomics}

NMR in plant metabolomics has a wide range of applications. Here we give a short overview of its different uses. For an extensive review we suggest Krishnan et al. (2005) and Ward et al. (2007). NMR has been used for quantitation of plant metabolites in mixtures and validation of reference materials as reviewed in Pauli et al. (2005). NMR analysis is a powerful tool for studying biosynthetic pathways using stable isotopes (e.g. ${ }^{13} \mathrm{C}$ ) including stability and kinetic studies of intermediates as reviewed by Ratcliffe and Shachar-Hill (2005) and Fan and Lane (2008). NMR analysis in plants comprises investigations into the impact of environmental factors, such as growth conditions (Lommen et al. 1998; Avelange-Macherel et al. 2006; Pereira et al. 2006; Charlton et al. 2008) exposure to metals (Bailey et al. 2003; Le Lay et al. 2006; Jahangir et al. 2008a), herbicides (Ott et al. 2003) and cultural practice (Neelam et al. 2008). NMR has been applied to study plant development stages (Palama et al. 2009) and plant hybridization (Kirk et al. 2005), to characterize plant ecotypes (Ward et al. 2003; Arany et al. 2008), as well as comparing wild-type and transgenic genotypes (Noteborn et al. 2000; Le Gall et al. 2003a; Choi et al. 2004a; Piccioni et al. 2009). NMR spectroscopy has been used for chemotaxonomic analysis (Choi et al. 2004b, 2005; Kim et al. 2005), the analysis of food products (McGorrin 2009) and phytomedicines (van der Kooy et al. 2009).

\section{Application of NMR to study host plant resistance}

Surprisingly, little use has been made of metabolomics to study interactions between plants and other organisms (Allwood et al. 2008). However, NMR plays a dominant role in those studies which have used a metabolomic approach investigating plantbiotic relationships. It has been NMR which has been applied as a proof of principle to show that metabolomics can constitute a major advancement in the study of host plant resistance using western flower thrips as a model. We will therefore focus on the use of NMR to study host plant resistance to thrips.

\section{Host plant resistance to western flower thrips (Frankliniella occidentalis)}

Leiss et al. (2009a, b) developed an eco-metabolomic approach (Fig. 1), based on NMR to identify candidate compounds for constitutive host plant resistance to western flower thrips (Frankliniella occidentalis). As a proof of principle this approach was applied to three different host systems, including Senecio as a wild plant (Leiss et al. 2009a), chrysanthemum as an ornamental (Leiss et al. 2009b) and tomato as a crop (Mirnezhad et al. 2009). Firstly, thrips-resistant and susceptible plants were identified applying in vivo thrips bioassays. The most resistant and the most susceptible plants were then chosen for NMR metabolomics. One and two-dimensional NMR was performed and the resulting metabolomic profiles of the thrips-resistant and susceptible plants were analysed with multivariate statistics like principal component analysis (PCA) and partial least square discriminant analysis (PLS-DA) to identify the metabolites involved in thrips resistance. For cross reference of resistance the metabolites in question were then, if possible, confirmed by a thrips in vitro bioassay. In all three host systems used the metabolomic profiles of thrips-resistant and susceptible plants were significantly different (Fig. 2) leading to a range of different metabolites involved in thrips resistance (Table 1).

In the wild plant Senecio a second generation hybrids of $S$. jacobeae and S. aquaticus was investigated for thrips resistance (Leiss et al. 2009b). Out of 33 hybrids the four most resistant and the four most susceptible ones were chosen for NMR analysis. Young and old leaves were investigated. As described in Leiss et al. (2009b) the thrips resistant hybrids contained significantly higher amounts of the pyrrolizidine alkaloids (PAs) Jacobine- and Jaconine 
Fig. 1 Eco-metabolomic approach to study host plant resistance in western flower thrips. ${ }^{1}$ For multivariate data analysis principal component analysis (PCA) and partial least squares regression-discriminant analysis (PLS-DA) were applied. For two dimensional NMR

${ }^{2}$ correlated spectroscopy, ${ }^{3}$ heteronuclear single quantum coherence, ${ }^{4}$ total correlated spectroscopyheteronuclear single quantum coherence and ${ }^{5}$ heteronuclear multiple bond correlation were used

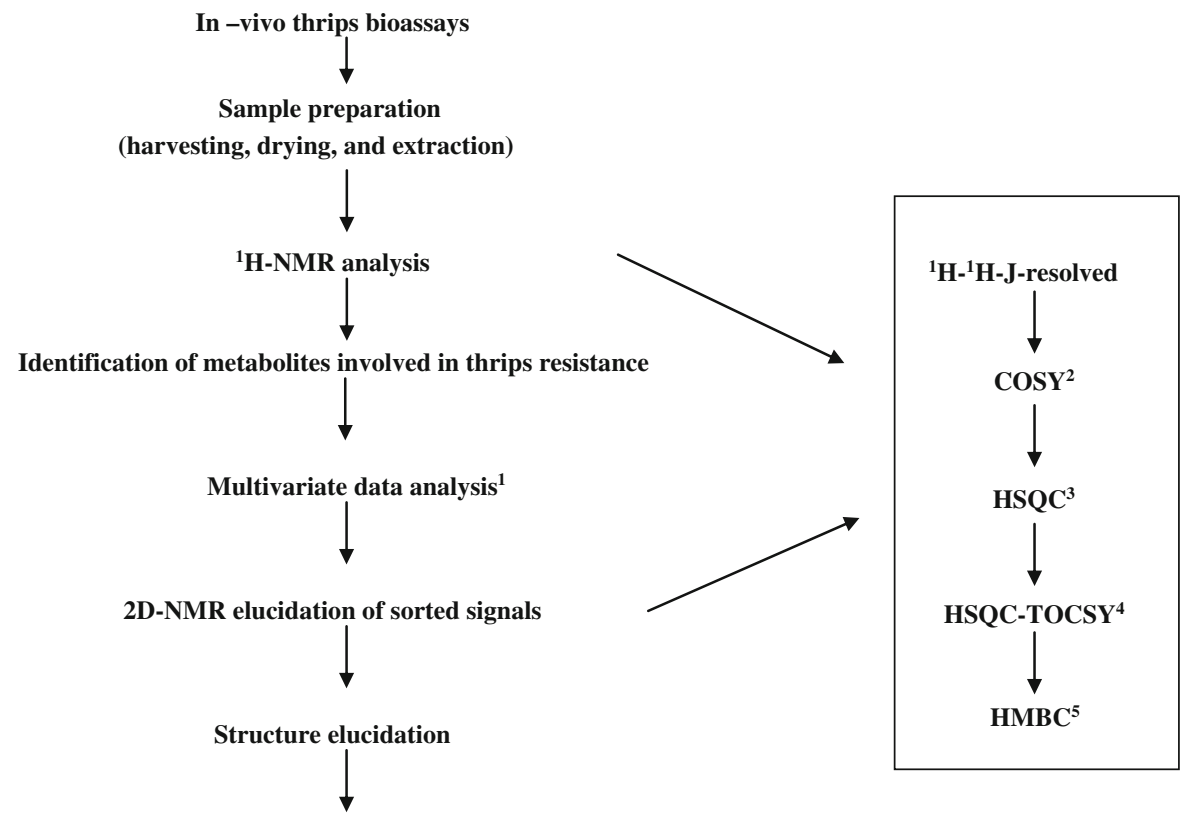

Quantification of metabolites involved in thrips resistance

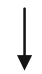

In-vitro thripsbioassays for cross reference of resistance
N-oxide and a flavanoid, kaempferol glucoside (Fig. 2a). PAs are regarded as constitutive defense compounds against generalist herbivores. They deter chewing insects such as caterpillars, locusts, beetles and aphids. In addition they show negative effects on fungi. Also flavanoids are known to be involved in plant resistance to herbivores. Kaempferol has a deterrent effect on generalist caterpillars and aphids. It is also effective against fungal pathogens. Young leaves of the thrips resistant plants showed significantly higher amounts of PAs and kaempferol glucoside compared to old leaves. In general young leaves contained more jacaranone. Analogues of jacaranone exhibited insecticidal activity on houseflies and generalist caterpillars. Young leaves being photosynthetically more active are more valuable plant parts compared to old leaves and thus need to be better defended. PAs are hepatotoxic to mammals, whereas kaempferol and jacaranone, showed antitumor activity on human cancer cell lines.

Ten cultivars, of which five were classified by breeders as thrips resistant and five as susceptible were tested for the ornamental chrysanthemum
(Dendrathema grandiflora) (Leiss et al. 2009a). As described in this paper the thrips resistant cultivars showed significantly higher amounts of the phenylpropanoids chlorogenic and feruloyl quinic acid (Fig. 2b). Phenols are known for their role in plant defense. Chlorogenic acid has been described as an antifeedant and digestibility reducer causing harmful effects on different caterpillar species, leaf beetles, leafhoppers and aphids. Chlorogenic acid also affects plant fungi and bacteria. Feruloyl quinic acid, which is closely related to chlorogenic acid, is an ester of quinic - and ferulic acid. The later is a precursor of lignin conferring rigidity to cell walls and as such it is linked to the resistance against stem borers and gall midges as well as against fungi. Both phenylpropanoids are not only implicated with the resistance to herbivores, they are also the most widespread natural plant dietary antioxidants and might be implicated in the prevention of cancer and cardiovascular diseases in humans.

For tomato 10 wild species and 10 cultivated lines were compared for thrips resistance (Mirnezhad et al. 2009). Cultivated tomatoes were much more 
A

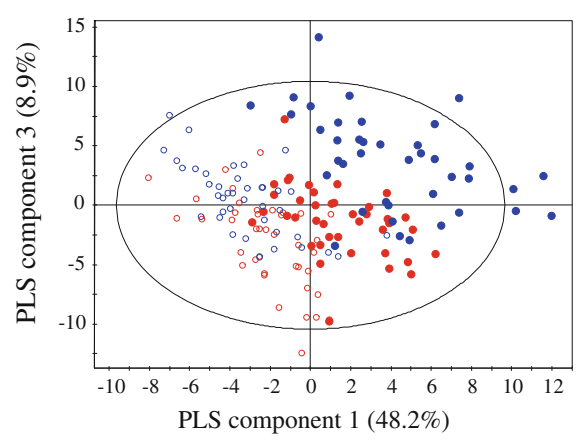

B

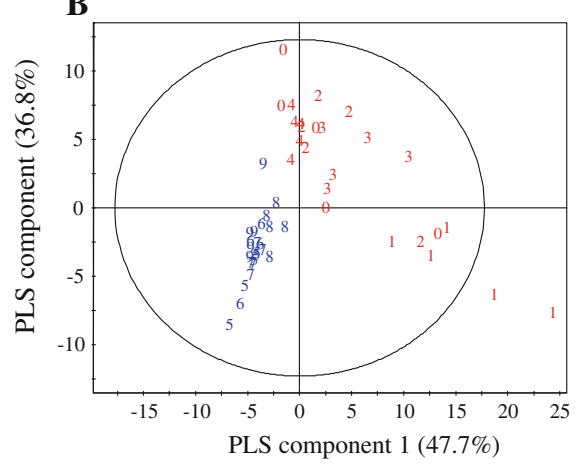

SIMCA-P+ 12 - 2009-04-18 13:13:58 (UTC+1)
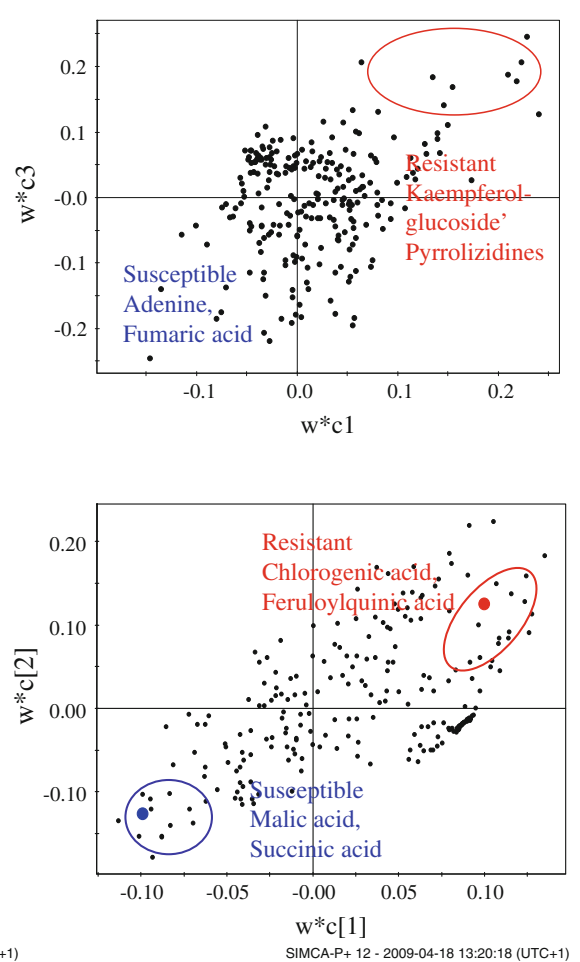

\section{C}

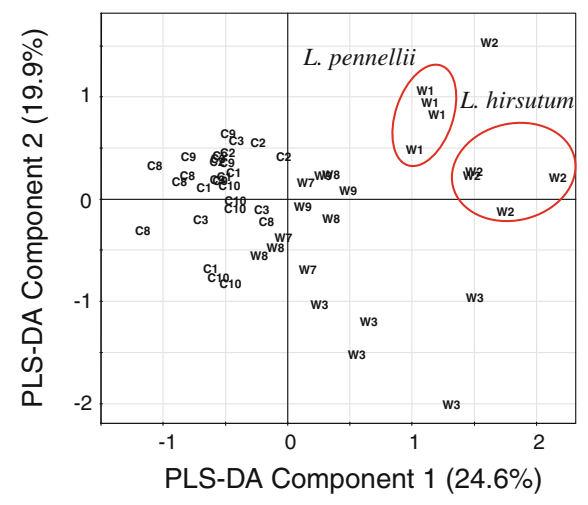

Fig. 2 Score and loading plots of partial least square regression - discriminate analysis based on ${ }^{1} \mathrm{H}-\mathrm{NMR}$ spectra of Senecio (A), chrysanthemum (B) and tomato (C) plants resistant (filled circle old leaves, open circle young leaves) and

susceptible to western flower thrips compared to the wild species. Three species/lines of each group, the wild and cultivated tomatoes, which where the most resistant or most susceptible, were subjected to NMR analysis. As described by Mirnezhad et al. (2009) the

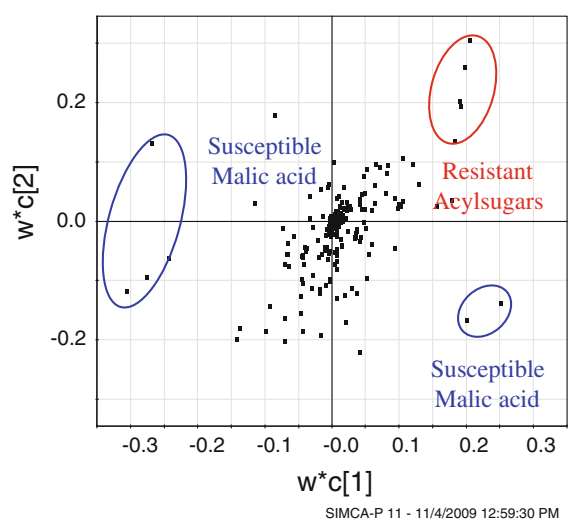

susceptible (filled circle old leaves, open circle young leaves) to western flower thrips. The ellipse represents the Hotelling T2 with $95 \%$ confidence in score plots

thrips resistant tomatoes contained acylsugars (Fig. 2c) which are known for their negative effect on caterpillars, leafminers, whiteflies and aphids. In contrast to chrysanthemum tomato contained relatively small amounts of chlorogenic acid. 


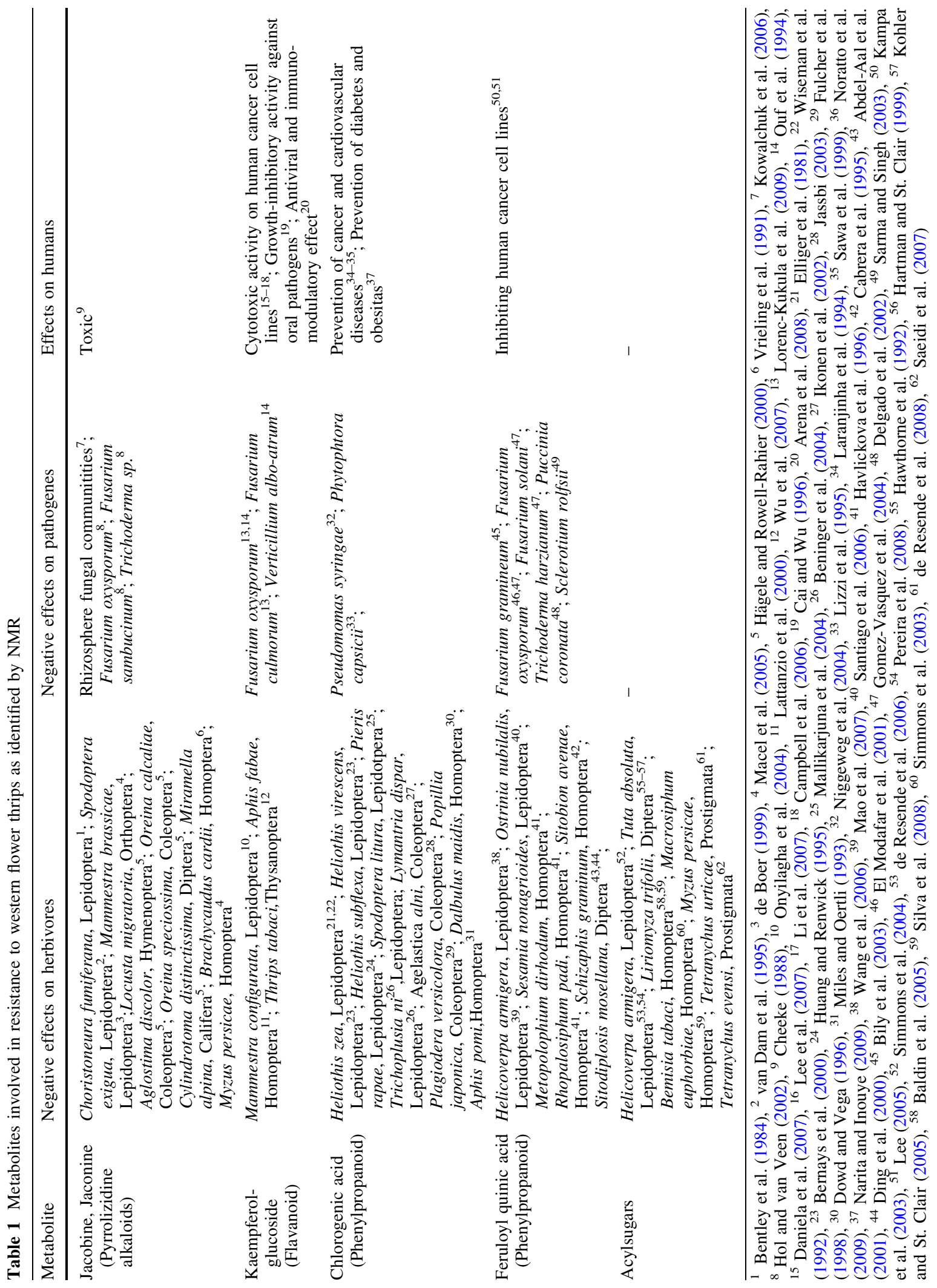




\section{Host plant resistance to other insects and pathogens}

Next to western flower thrips there is only one more study applying NMR on insects, investigating induced resistance. Widarto et al. (2006) showed that both the effect of the generalist Spodoptera exigua and the specialist Plutella xylostella on Brassica rapa were depended on the larval stage. While the second larval instars of the generalist increased levels of glucose, ferulic acid and gluconapin, the fourth instar caused an increase in levels of alanine and sinapoyl malate. Second larval instars of the specialist accumulated glucose, feruloyl and sinapoyl malate and gluconapin, whereas the fourth instars stimulated the plant to accumulate more sucrose.

Most NMR studies looking at the effect of pathogen infection on a host plant investigated induced resistance by analyzing the metabolome of the infected and non-infected hosts. Infection by phytoplasma Catharanthus roseus caused an increase of metabolites related to the biosynthetic pathways of phenylpropanoids and terpenoid indole alkaloids (Choi et al. 2004c). Fructose, in contrast to glucose, which accumulated in infected leaves, was involved in the phytopathogenicity in Spiroplasma citri (Andre et al. 2005). A range of compounds including chlorogenic acid, $\alpha$-linolenic acid analogues, sesquiterpenoids and diterpenoids were increased in tobacco infected with tobacco mosaic virus (Choi et al. 2006). Metabolic changes in B. rapa varied with the type of bacterial species. While threonine and GABA were detected to be the discriminating metabolites in Grampositive bacteria treated plants, those treated with Gram-negative bacteria exhibited a significant increase in sinapoyl-malate, caffeoyl-malate and histidine (Jahangir et al. 2008b). Metabolomic changes in B. rapa to disarmed and tumor-inducing strains of Agrobacterium tumefaciens constituted significant differences in flavanoid, phenylpropanoid, sugar and free amino/organic acid contents (Simoh et al. 2009). The root-pathogenic oomycte Pythium sylvaticum caused an increase in indolics and a decrease in three phenylpropanoids upon infection of root cultures of Arabidopsis thaliana wild type (Bednarek et al. 2005). Fungal infection of $B$. rapa with Leptosphaeria maculans, Aspergillus niger or Fusarium oxysporum was associated with the presence of phenylpropanoids, flavanoids and glucosinulates, whereby specific patterns were depended on fungal species and host plant cultivar (Abdel-Farid et al. 2009).

Relatively little attention has been given to use NMR to study constitutive host plant resistance to pathogens. There are two studies on the host plant resistance to fungi on grapes. In comparison to susceptible grapevine cultivars, those resistant to mildews accumulated inositol and caffeic acid, two compounds known to confer resistance to fungi (Figueiredo et al. 2008). Differentiation of grape cultivars based on their resistance to downy mildew was based on quercitin-3-o-glucoside and a transferuloyl derivative (Ali et al. 2009).

\section{Conclusion and future prospects}

NMR-based metabolomics proved to be a promising tool to identify metabolites involved in host plant resistance. It can provide key information for the development and implementation of host plant resistance. As shown by the eco-metabolomic approach, studying thrips resistance, NMR led to the successful identification of different candidate compounds in three different plant species. Especially those compounds such as kaempferol and phenylpropanoids are very valuable candidates to develop host plant resistance in agricultural crops. Not only do they inhibit pests but they also show inhibiting effects on human cancer cell lines. Combining host plant resistance to pests with healthy food characters is a promising future prospect. Indeed, a tomato with increased amounts of kaempferol glucoside (Le Gall et al. 2003b) as well as a tomato with a doubled amount of chlorogenic acid (Niggeweg et al. 2004) have been engineered for dietary purposes.

The next challenge in studying herbivore resistance with metabolomics will be to undertake compartmentalized NMR-metabolomics to study composition of those tissues the insects feed upon. Thrips, for instance, are cell feeders ingesting whole plant cells, including the vacuoles in which many of the plant defense compounds, like pyrrolizidine alkaloids and phenylpropanoids are stored. Furthermore, thrips probing is characterized by shallow feeding in the epidermal tissue while, thrips penetration feeding effects mesophyll cells (van de Wetering et al. 1998).

NMR allows the simultaneous detection of a wide range of metabolites, providing an instantaneous 
profile of the metabolome of the resistant plant. NMR applied to thrips resistance in different host systems, including wild plants, ornamentals and crops, showed that the eco-metabolomic approach is universal. It may be applied to any economically important agricultural ornamental or crop and, while thrips has been used as a model, it can be applied to any other key herbivore and pathogen. Once the metabolites involved in host plant resistance are known, the resistance of plants can be predicted on the basis of their metabolomic profile. Thus using NMR a single test may be sufficient in the future to predict resistance to different pests/pathogens simultaneously. At the time resistance to each pest/ pathogen needs to be tested separately, leading to a whole array of time consuming and costly tests. Applying general standard protocols for NMR measurements, a greatly reproducible, high throughput NMR screening facility could be realized. It would establish the metabolomic profiles of ornamentals and crops resistant to the economically most important pests and pathogens and store these in a metabolomic profile library. Since NMR is the only metabolomic method where the physical characteristics of compounds will always be the same it is the method of choice for a long-lasting database (Verpoorte et al. 2008). Comparing the profiles in the data base with the profiles of screened plants can then predict resistance. Furthermore, with the opportunity to detect metabolites which are involved in the resistance to different organisms NMR may facilitate multi-resistance breeding.

NMR based metabolomics using the eco-metabolomic approach, comparing the metabolome of resistant and susceptible plants has a vast potential in the identification of secondary plant defense compounds involved in resistance to herbivores and pathogens, which will drive future resistance breeding and biopesticide development.

Open Access This article is distributed under the terms of the Creative Commons Attribution Noncommercial License which permits any noncommercial use, distribution, and reproduction in any medium, provided the original author(s) and source are credited.

\section{References}

Abdel-Aal ESM, Hucl P, Sosluski FW, Graf R, Gillot C, Pietrzak L (2001) Screening spring wheat for midge resistance in relation to ferulic acid content. J Agric Food Chem 49:3559-3566

Abdel-Farid IB, Jahangir M, van den Hondel CAMJJ, Kim HK, Choi YH, Verpoorte R (2009) Fungal infection-induced metabolites in Brassica rapa. Plant Sci 176:608-615

Ali K, Maltese F, Zyprian E, Rex M, Choi HY, Verpoorte R (2009) NMR metabolomic fingerprinting based identification of grapevine metabolites associated with downy mildew resistance. J Agric Food Chem 57:9599-9606

Allwood JW, Ellis DI, Goodacre R (2008) Metabolomic technologies and their application to the study of plants and plant-host interactions. Physiol Plant 132:117-135

Andre A, Maucourt M, Moing A, Rolin D, Renaudin J (2005) Sugar import and phtyopathogenicity of Spiroplasma citri: glucose and fructose play distinct roles. Mol Plant Microb Interact 18:33-42

Arany AM, de Jong TJ, Kim HK, van Dam NM, Choi YH, Verpoorte R, van der Meijden E (2008) Glucosinulates and other metabolites in the leaves of Arabidopsis thaliana from natural populations and their effect on a generalist and a specialist herbivore. Chemoecology 18: $65-71$

Arena A, Bisignano G, Pavone B, Tomaino A, Bonina FP, Saija A, Cristani M, D' Arrigo M, Trombetta D (2008) Antiviral and immunomodulatory effect of a lyophilized extract of Capparis spinosa L. buds. Phytother Res 22:313-317

Avelange-Macherel M-H, Ly-Vu B, Delauny J, Richomme P, Leprince O (2006) NMR metabolite profiling analysis reveals changes in phospolipid metabolism associated with the re-establishment of desiccation tolerance upon osmotic stress in germinated radicals of cucumber. Plant Cell Environ 29:471-482

Bailey NJC, Oven M, Holmes E, Nicholson JK, Zenk MH (2003) Metabolomic analysis of the consequences of cadmium exposure in Silene cucubalus cell cultures via ${ }^{1} \mathrm{H}$ NMR spectroscopy and chemometrics. Phytochemistry 62:851-858

Baldin ELL, Vendramim JD, Lourencao AL (2005) Resistance of tomato genotypes to the whitefly Bemisia tabaci (Gennadius) biotype B (Hemiptera: Aleyrodidae). Neotrop Entomol 34:435-441

Bednarek P, Schneider B, Svatos A, Oldham NJ, Hahlbrock K (2005) Structural complexity, differential response to infection, and tissue specificity of indolic and phenylpropanoid secondary metabolism in Arabidopsis roots. Plant Phys 138:1058-1070

Benderoth M, Textor S, Windsor AJ, Mitchell-Olds T, Gershenzon J, Kroyman J (2006) Positive selection driving diversification in plant secondary metabolism. Proc Nat Acad Sci USA 103:9118-9123

Beninger CW, Abou-Zaid MM, Kistner ALE, Hallett RH, Iqbal MJ, Grodzinski B, Hall JC (2004) A flavanone and two phenolic acids from Crysanthemum morifolium with phytotoxic and insect growth regulating activity. J Chem Ecol 30:589-606

Bennett RN, Wallsgrove RM (1994) Tansley review No. 72: secondary metabolites in plant defence mechanisms. New Phytol 127:617-633

Bentley M, Leonard D, Stoddard DE, Zalkow LH (1984) Pryrolozidine alkaloids as larval feeding deterrents for 
spruce budworm, Choristoneura fumiferana (Lepidoptera: Tortiricidae). Ann Entomol Soc Am 77:393-397

Bernays EA, Oppenheim S, Chapman RF, Kwon H, Gould F (2000) Taste sensitivity of insect herbivores to deterrents is greater in specialists than in generalists: a behavioral test of the hypothesis with two closely related caterpillars. J Chem Ecol 26:547-563

Bily AC, Reid LM, Taylor JH, Johnston D, Malouin C, Burt AJ, Bakan B, Regnault-Roger C, Pauls KP, Arnason JT, Philogene BJR (2003) Dehydromers of ferulic acid in maize pericarp and aleurone: resistance factors to Fusarium gramineum. Phytopathology 93:712-719

Cabrera HM, Munoz O, Zuniga GE, Corcuera LJ, Argandona VH (1995) Changes in ferulic acid and lipid content in aphid-infested barley. Phytochemistry 39:1023-1026

Cai LN, Wu CD (1996) Compounds from Syzygium aromaticum possessing growth inhibitory activity against oral pathogens. J Nat Prod 59:987-990

Campbell JK, King JL, Harmston M, Lila MA, Erdman JW (2006) Synergistic effects of flavanoids on cell proliferation in Hepa-1c 1c 7 and LNCaP cancer cell lines. J Food Sci 71:S358-S363

Charlton AJ, Donarksi JA, Harrison M, Jones SA, Godward J, Oehlschlager S, Arques JL, Ambrose M, Chinoy C, Mullineaux PM, Domoney C (2008) Responses of the pea (Pisum sativum L.) leaf metabolome to drought stress assessed by nuclear magnetic resonance spectroscopy. Metabolomics 4:312-327

Cheeke PR (1988) Toxicity and metabolism of pyrrolizidine alkaloids. J Anim Sci 66:2343-2350

Choi HK, Choi YH, Verberne M, Lefeber AWM, Erkelens C, Verpoorte R (2004a) Metabolic fingerprinting of wild type and transgenic tobacco plants by $1 \mathrm{H}-\mathrm{NMR}$ and multivariate analysis techniques. Phytochemistry 65:857-864

Choi YH, Kim HK, Hazekamp A, Erkelens C, Lefeber AMW, Verpoorte R (2004b) Metabolomic differentiation of Cannabis sativa cultivars using 1H-NMR and principal component analysis. J Nat Prod 67:953-957

Choi YH, Tapias EC, Kim HK, Lefeber AWM, Erkelens C, Verhoeven JTJ, Brzin J, Zei J, Verpoorte R (2004c) Metabolic discrimination of Catharantus roseus leaves infected by phytoplasma using ${ }^{1} \mathrm{H}-\mathrm{NMR}$ spectroscopy and multivariate data analysis. Plant Physiol 135:2398-2410

Choi YH, Sertic S, Wilson EG, Michopoulos F, Lefeber AWM, Erkelens C, Kricun SPD, Verpoorte R (2005) Classification of Ilex species based on metabolomic fingerprinting using nuclear magnetic resonance and multivariate data analysis. J Agic Food Chem 53:1237-1245

Choi YH, Kim HK, Linthorst HJM, Hollander JG, Lefeber AWM, Erkenlens C, Nuzillard J-M, Verpoorte R (2006) NMR metabolomics to revisit the tobacco mosaic virus infection in Nicotiana tabacum leaves. J Nat Prod 69: $742-748$

Coelho S (2009) European pesticide rules promote resistance, researchers warn. Science 323:450

Daniela A, Pichichero E, Canuti L, Cicconi R, Karou D, D'Arcangelo G, Canini A (2007) Identification of phenolic compounds from medicinal and melliferous plants and their cytotoxic activity in cancer cells. Caryologia 60:90-95 de Boer NJ (1999) Pyrrolizidine alkaloid distribution in Senecio jacobaea rosettes minimises losses to generalist feeding. Entomol Exp Appl 91:169-173

de Resende JTV, Maluf WR, Faria MV, Pfann AZ, do Nascimento ER (2006) Acylsugars in tomato leaflets confer resistance to the South American tomato pinworm, Tuta absoluta Meyr. Sci Agric 63:20-25

de Resende JTV, Maluf WR, Cardoso MD, Faria MV, Goncalves LD, do Nascimento IR (2008) Resistance of tomato genotypes with high level of acylsugars to Tetranychus evansi Baker \& Pritchard. Sci Agric 65:31-35

Delgado NJ, Casler MD, Grau CR, Jung HG (2002) Reactions of smooth bromegrass clones with divergent lignin or etherified ferulic acid concentration to three fungal pathogens. Crop Sci 42:1824-1831

Denholm I, Rowland MW (1992) Tactics for managing pesticide resistance in arthropods: theory and practice. Annu Rev Entomol 37:91-112

Dent D, Elliott C (1995) Integrated pest management. Chapman \& Hall, London

Ding H, Lamb RJ, Ames N (2000) Inducible production of phenolic acids in wheat and antibiotic resistance to Sitodiplosis mosellana. J Chem Ecol 26:969-985

Dowd PF, Vega FE (1996) Enzymatic oxidation products of allelochemicals as a basis for resistance against insects: effects on the corn leafhopper Dalbulus maidis. Nat Toxins 4:85-91

El Modafar C, El Boustani E (2001) Cell-wall bound phenolic acid and lignin contents in date palm as related to its resistance to Fusarium oxysporum. Biol Plant 44:125-130

Elliger CA, Wong Y, Chan BG, Waiss AC Jr (1981) Growth inhibitors in tomato (Lycopersicon) to tomato fruitworm (Heliothis zea). J Chem Ecol 7:753-758

Fan TW-M (1996) Metabolite profiling by one- and twodimensional NMR analysis of complex mixtures. Prog Nucl Magn Reson Spectr 28:161-219

Fan TW-M, Lane AN (2008) Structure-based profiling of metabolites and isotopomers by NMR. Progr Nucl Magn Reson Spectr 52:69-117

Figueiredo A, Fortes AM, Ferreira S, Sebastiana M, Choi YH, Sousa L, Acioli-Santos B, Pessoa F, Verpoorte R, Pais MS (2008) Transcriptional and metabolic profiling of grape (Vitis vinifera L.) leaves unravel possible innate resistance against pathogenic fungi. J Exp Bot 59:3371-3381

Fulcher AF, Ranney TG, Burton JD, Walgenbach JF, Danehower DA (1998) Role of foliar phenolics in host plant resistance of Malus taxa to adult Japanese beetle. Hortscience 33:862-865

Gomez-Vasques R, Day R, Buschmann H, Randles S, Beeching JR, Cooper RM (2004) Phenylpropanoids, phenylalanine ammonia lyase and peroxidases in elicitorchallenged cassava (Manihot esculenta) suspension cells and leaves. Ann Bot 94:87-97

Grotewold E (2005) Plant metabolic diversity: a regulatory perspective. Trends Plant Sci 10:57-62

Hägele BF, Rowell-Rahier M (2000) Choice, performance and heritability of performance of specialist and generalist insect herbivores towards cacalol and seneciphylline, two allelochemicals of Adenostyles alpine (Asteraceae). J Evol Biol 13:131-142 
Hartman JB, St. Clair DA (1999) Variation for aphid resistance and insecticidal acyl sugar expression among and within Lycopersicon pennellii-derived inbred backcross lines of tomato and their F-1 progeny. Plant Breed 118:531-536

Hartmann T (2007) From waste products to ecochemicals: fifty years research of plant secondary metabolism. Phytochem 68:2831-2846

Hatada K, Kitayama T (2004) Basic principles of NMR. In: Hatada K, Kitayama T (eds) NMR spectroscopy of polymers. Springer, New York

Havlickova H, Cvikrova M, Eder J (1996) Phenolic acids in wheat cultivars in relation to plant suitability for and response to cereal aphids. Z Pflanzenkr Pflanzenschutz-J Plant Dis Prot 103:535-542

Hawthorne DJ, Shapiro JA, Tingey WM, Mutschler MA (1992) Trichome-borne and artificially applied acylsugars of wild Tomato deter feeding and oviposition of the leafminer Liriomyza trifolii. Entomol Exp Appl 65:65-73

Hol WHG, van Veen JA (2002) Pyrrolizidine alkaloids from Senecio jacobaea affect fungal growth. J Chem Ecol 28:1763-1772

Huang XP, Renwick JAA (1995) Chemical and experimental basis for rejection of Tropaeolum majus by Pieris rapae larvae. J Chem Ecol 21:1601-1617

Ikonen A, Tahvanainen J, Roininen H (2002) Phenolic secondary compounds as determinants of the host plant preferences of the leaf beetle Agelastica alni. Chemoecology 12:125-131

Jahangir M, Abdel-Farid IB, Choi YH, Verpoorte R (2008a) Metal ion-inducing metabolite accumulation in Brassica rapa. J Plant Physiol 165:1429-1437

Jahangir M, Kim HK, Choi YH, Verpoorte R (2008b) Metabolomic response of Brassica rapa submitted to pre-harvest bacterial contamination. Food Chem 107:362-368

Jassbi AR (2003) Secondary metabolites as stimulants and antifeedants of Salix integra for the leaf beetle Plagiodera versicolora. Z Naturforsch Teil C-J Biosci 58:573-579

Kampa M, Alexaki V-I, Notas G, Nifli A-P, Nistikaki A, Hatzoglou A, Bakogeorgou E, Kouimtzoglou E, Blekas G, Boskou D, Gravanis A, Castanas E (2003) Antiproliferative and apoptotic effects or selective phenolic acids on 747D human breast cancer cells: potential mechanisms of action. Breast Cancer Res 6:R63-R74

Kennedy GG, Barbour JD (1992) Resistance variation in natural and managed systems. In: Fritz RS, Slimms EL (eds) Plant resistance to herbivores and pathogens. University of Chicago Press, Chicago

Kim HK, Choi YH, Erkelens C, Lefeber AWM, Verpoorte R (2005) Metabolic fingerprinting of Ephedra species using H-1-NMR spectroscopy and principal component analysis. Chem Pharm Bull 53:105-109

Kirk H, Choi YH, Kim HK, Verpoorte R, van der Meijden E (2005) Comparing metabolomes: the chemical consequences of hybridization in plants. New Phytol 167:613-622

Kohler GR, St. Clair DA (2005) Variation for resistance to aphids (Homoptera: Aphididae) among tomato inbred backcross lines derived from wild Lycopersicon species. J Econ Entomol 98:988-995

Kopka J, Fernie A, Weckwerth W, Gibon Y, Stitt M (2004) Metabolite profiling in plant biology: platforms and destinations. Gen Biol 5:109.1-109.9
Kowalchuk GA, Hol WHG, van Veen JA (2006) Rhizosphere fungal communities are influenced by Senecio jacobaea pyrrolizidine alkaloid content and composition. Soil Biol Biochem 38:2852-2859

Krishnan P, Kruger NJ, Ratcliffe RG (2005) Metabolite fingerprinting and profiling in plants using NMR. J Exp Bot 56:255-265

Laranjinha JA, Almeida LM, Madeira VM (1994) Reactivity of dietary phenolic acids with peroxyl radicals: antioxidant activity upon low density lipoprotein peroxidation. Biochem Pharmacol 48:487-494

Lattanzio V, Arpaia S, Cardinali A, di Venere D, Linsalata V (2000) Role of endogenous flavanoids in resistance mechanism of Vigna to aphids. J Agric Food Chem 48:5316-5320

Le Gall G, Colquhoun IJ, Davis AL, Collins GJ, Verhoeyen ME (2003a) Metabolite fingerprinting of tomato (Lycopersicon esculentum) using ${ }^{1} \mathrm{H}$ NMR spectroscopy as a tool to detect potential unintended effects following a genetic modification. J Agric Food Chem 51:2447-2456

Le Gall G, Dupont MS, Mellon FA, Davis AL, Collins GJ, Verhoeyen ME, Colquhoun IJ (2003b) Characterization and content of flavonoid glycosides in genetically modified tomato (Lycopersicon esculentum) fruits. J Agric Food Chem 51:2438-2446

Le Lay P, Isaure MP, Sarry JE, Kuhn L, Fayard B, Le Bail JL, Bastien O, Garin J, Roby C, Bourguignon J (2006) Metabolomic, proteomic and biophysical analyses of Arabidopis thaliana cells exposed to caesium stress. Influence on potassium supply. Biochemie 88:153-1547

Lee YS (2005) Role of NADPH oxidase-mediated generation of reactive oxygen species in the mechanism of apoptosis induced by phenolic acids in HepG2 human heptoma cells. Arch Pharm Res 28:1183-1189

Lee EJ, Choi EJ, Choi CI, Park JS, Sung MK (2007) Effects of anti-inflammatory quercetin and kaempferol on cell growth and the production of angiogenic factors in HT-29 human colon cancer cells. FASEB 21:A1092

Leiss KA, Maltese F, Choi YH, Verpoorte R, Klinkhamer PGL (2009a) Identification of chlorogenic acid as a resistance factor for thrips in chrysanthemum. Plant Physiol 150:1567-1575

Leiss KA, Choi YH, Abdel-Farid IB, Verpoorte R, Klinkhamer PGL (2009b) NMR metabolomics of thrips (Frankliniella occidentalis) resistance in Senecio hybrids. J Chem Ecol 35:219-229

Li YL, Gan GP, Zhang HZ, Wu HZ, Li CL, Huang YP, Liu YW, Liu JW (2007) A flavonoid glycoside isolated from Smilax china L. rhizome in vitro anticancer effects on human cancer cell lines. J Ethnopharmacol 113:115-124

Lizzi Y, Roggero JP, Coulomb PJ (1995) Behaviour of the phenolic compounds on Capsicum annuum leaves infected with Phytophtora capsici. J Phytopathol 143: 619-627

Lommen A, Weseman JM, Smith GO, Noteborn HPJM (1998) On the detection of the environmental effects on complex matrices combining off-line liquid chromatography and ${ }^{1} \mathrm{H}$ NMR. Biodegradation 9:513-525

Lorenc-Kukula K, Zuk M, Kulma A, Czemplik M, Kostyn K, Skala J, Starzycki M, Szopa J (2009) Engineering flax with the GT family 1 Solanum sogarandinum 
glycosyltransferase SsGT1 confers increased resistance to Fusarium infection. J Agric Food Chem 57:6698-6705

Macel M, Bruinsma M, Dijkstra SM, Ooijendijk T, Niemeyer HM, Klinkhamer PGL (2005) Differences in effects of pyrrolizidine alkaloids on five generalist insect herbivore species. J Chem Ecol 31:1493-1508

Mallikarjuna N, Kranthi KR, Jadhav DR, Kranthi S, Chandra S (2004) Influence of foliar chemical compounds on the development of Spodoptera litura (Fab.) in interspecific derivatives of groundnut. J Appl Entomol 128:321-328

Mao JQ, Burt AJ, Ramputh AI, Simmonds J, Cass L, Hubbard K, Miller S, Altosaar I, Arnason JT (2007) Diverted secondary metabolism and improved resistance to European corn borer (Ostrinia nubilalis) in maize (Zea mays L.) transformed with wheat oxalate oxidase. J Agric Food Chem 55:2582-2589

McGorrin RJ (2009) One hundred years of progress in food analysis. J Agric Food Chem 57:8076-8088

Miles PW, Oertli JJ (1993) The significance of antioxidants in the aphid-plant interaction: the redox hypothesis. Entomol Exp Appl 67:275-283

Mirnezhad M, Romero-González RR, Leiss KA, Choi YH, Verpoorte R, Klinkhamer PGL (2009) Metabolomic analysis of host plant resistance to thrips in wild and cultivated tomatoes. Phytochem Anal (in press). doi $10.1002 /$ pca. 1182

Narita Y, Inouye K (2009) Kinetic analysis and mechanism on the inhibition of chlorogenic acid and its components against porcine pancreas alpha-amylase isozymes I and II. J Agric Food Chem 57:9218-9225

Neelam A, Cassol T, Mehta RA, Abdul-Baki AA, Sobolev AP, Goyal RK, Abbott J, Segre AL, Handa AK, Mattoo AK (2008) A field grown transgenic tomato line expressing higher levels of polyamines reveals legume cover crop mulch-specific perturbations in fruit phenotype at the levels of metabolite profiles, gene expression, and agronomic characteristics. J Exp Bot 59:23372346

Niggeweg R, Michael AJ, Martin C (2004) Engineering plants with increased levels of the antioxidant chlorogenic acid. Nature Biotechnol 22:746-754

Noratto G, Porter W, Byrne D, Cisneros-Zevallos L (2009) Identifying peach and plum polyphenols with chemopreventive potential against estrogen-independent breast cancer cells. J Agr Food Chem 57:5219-5226

Noteborn HPJM, Lommen A, van der Jagt RC, Weseman JM (2000) Chemical fingerprinting for the evaluation of unintended secondary metabolite changes in transgenic food crops. J Biotechnol 77:103-114

Onyilagha JC, Lazorko J, Gruber MY, Soroka JJ, Erlandson MA (2004) Effect of flavonoids on feeding preference and development of the crucifer pest Mamestra configurata Walker. J Chem Ecol 30:109-124

Ott K-H, Aranibar N, Singh B, Stockton GW (2003) Metabolomics classifies pathways affected by bioactive compounds. Artifical neural network classification of NMR spectra of plant extracts. Phytochemistry 62:971-985

Ouf SA, Hady FKA, Elgamal MH, Shaker KH (1994) Isolation of antifungal compounds from some Zygophyllum species and their bioassay against 2 soil-borne plant-pathogens. Folia Microbiol 39:215-221
Palama TL, Khatib A, Choi YH, Payet B, Fock I, Verpoorte R, Kodja H (2009) Metabolic changes in different developmental stages of Vanilla planifolia pods. J Agric Food Chem 57:7651-7658

Pauli GF, Jaki BU, Lankin DC (2005) Quantitative H-1 NMR: development and potential of a method for natural product analysis. J Nat Prod 68:133-149

Pereira GE, Gaudillere JP, Van Leeuwen C, Hilbert G, Maucourt M, Deborde C, Moing A, Rolin D (2006) H-1 NMR metabolite fingerprints of grape berry: comparison of vintage and soil effects in Bordeaux grapevine growing areas. Anal Chim Acta 563:346-352

Pereira GVN, Maluf WR, Goncalves LD, do Nascimento DR, Gomes LAA, Licursi V (2008) Selection towards high acylsugar levels in tomato genotypes and its relationship with resistance to spider mite (Tetranychus evansi) and to the South American pinworm (Tuta absoluta). Cienc Agrotec 32:996-1004

Piccioni F, Capitani D, Zolla L, Mannina L (2009) NMR metabolic profiling of transgenic maize with the Cryl A(b) gene. J Agric Food Chem 57:6041-6049

Ratcliffe RG, Shachar-Hill Y (2005) Revealing metabolic phenotypes in plants: inputs from NMR analysis. Biol Rev 80:27-43

Ratcliffe RG, Roscher A, Shachar-Hill Y (2001) Plant NMR spectroscopy. Prog Nucl Reson Spectr 39:267-300

Saeidi Z, Mallik B, Kulkarni RS (2007) Inheritance of glandular trichomes and two-spotted spider mite resistance in cross Lycopersicon esculentum "Nandi" and L. pennellii "LA2963". Euphytica 154:231-238

Santiago R, Butron A, Arnason JT, Reid LM, Souto XC, Malvar RA (2006) Putative role of pith cell wall phenylpropanoids in Sesamia nonagrioides (Lepidoptera: Noctuidae) resistance. J Agric Food Chem 54:2274-2279

Sarma BK, Singh UP (2003) Ferulic acid may prevent infection of Cicer arietinum by Sclerotium rolfsii. World J Microbiol Biotechnol 19:123-127

Sawa T, Nakao M, Akaike T, Ono K, Maeda H (1999) Alkylperoxyl radical-scavenging activity of various flavonoids and other phenolic compounds: implications for the anti-tumor-promoter effect of vegetables. J Agric Food Chem 47:397-402

Silva VD, Cardoso MD, de Moraes JC, Pimentel FA, Goncalves LD, Neri DKP (2008) Characterization and evaluation of synthetic acylsugar on the behavior of the whitefly Bemisia tabaci (Gennadius, 1886) b biotype (Hemiptera: aleyrodida) in tomato plant. Cienc Agrotec 32:1408-1412

Simmons AT, Gurr GM, McGrath D, Nicol HI, Martin PM (2003) Trichomes of Lycopersicon spp. and their effect on Myzus persicae (Sulzer) (Hemiptera: Aphididae). Aust J Entomol 42:373-378

Simmons AT, Gurr GM, McGrath D, Martin PM, Nicol HI (2004) Entrapment of Helicoverpa armigera (Hubner) (Lepidoptera : Noctuidae) on glandular trichomes of Lycopersicon species. Aust J Entomol 43:196-200

Simoh S, Quintana N, Kim HK, Choi YH, Verpoorte R (2009) Metabolic changes in Agrobacterium tumefasciens-infected Brassica rapa. J Plant Physiol 166:1005-1014

van Dam NM, Vuister LWM, Bergshoeff C, de Vos H, van der Meijden E (1995) The 'raison d'être' of pyrrolizidine 
alkaloids in Cynoglossum officinale: deterrent effects against generalist herbivores. J Chem Ecol 21:507-523

van de Wetering F, Hulshof J, Posthuma K, Harrewijn P, Goldbach R, Peters D (1998) Distinct feeding behavior between sexes of Frankliniella occidentalis results in higher scar production and lower tospovirus transmission by females. Entomol Exp Appl 88:9-15

van der Kooy F, Maltese F, Choi YH, Kim HK, Verpoorte R (2009) Quality control of herbal material and phytopharmaceuticals with MS and NMR based metabolic fingerprinting. Planta Med 75:763-775

Verpoorte R, Choi YH, Kim HK (2007) NMR-based metabolomics at work in phytochemistry. Phytochem Rev 6: 3-14

Verpoorte R, Choi YH, Mustafa NR, Kim HK (2008) Metabolomics: back to basics. Phytochem Rev 7:525-537

Vrieling K, Soldaat LL, Smit W (1991) The influence of pyrrolizidine alkaloids of Senecio jacobaea on Tyria jacobaea, Brachycaudus cardii and Haplothrips senecionis. Neth J Zool 41:228-239

Wang Y, Cai QN, Zhang QW, Han Y (2006) Effect of secondary substances from wheat on the growth and digestive physiology of cotton bollworm Helicoverpa armigera (Lepidoptera: Noctuidae). Eur J Entomol 103:255-258
Ward JL, Harris C, Lewis J, Beale MH (2003) Assessment of ${ }^{1} \mathrm{H}$ NMR spectroscopy and multivariate analysis as a technique for metabolite fingerprinting of Arabidopsis thaliana. Phytochemistry 62:949-957

Ward JL, Baker JM, Beale MH (2007) Recent applications of NMR spectroscopy in plant metabolomics. FEBS J 274:1126-1131

Widarto HT, van der Meijden E, Lefeber AWM, Erkelens C, Kim HK, Choi YH, Verpoorte R (2006) Metabolomic differentiation of Brassica rapa following herbivory by different insect instars using two-dimensional nuclear magnetic resonance spectroscopy. J Chem Ecol 32:24172428

Wink M (2003) Evolution of secondary metabolites from an ecological and molecular phylogenetic perspective. Phytochem 64:3-19

Wiseman BR, Snook ME, Wilson RL, Isenhour DJ (1992) Allelochemical content of selected popcorn silks-effects on growth of corn earworm larvae (Lepidoptera, Noctuidae). J Econ Entomol 85:2500-2504

Wu B, Takahashi T, Kashiwagi T, Tebayashi S-I, Kim C-S (2007) New flavonoid glycosides from the leaves of Solidago altissima. Chem Pharm Bull 55:815-816 